\title{
Effect of Hydrostatic Pressure and Soil Characteristics on Stability of Dumps
}

\author{
${ }^{* 1}$ M. S. Tiwari, ${ }^{2}$ P. B. Kulkarni, ${ }^{3}$ E M Gonnade, ${ }^{4}$ B. P Chelani \\ 1,2,3,4 Shri Ramdeobaba College of Engineering and Management, Nagpur \\ Email:tiwarims@rknec.edu,kulkarnipb@rknec.edu,gonnadeem@rknec.edu, bchelani@rediffmail.com
}

Received: 14th November 2019, Accepted: 31st January 2020, Published: 29th February 2020

\begin{abstract}
This paper deals with the case study of dump slopes stability analysis of an opencast mine near Nagpur, Maharashtra, India. The study considers cohesion, angle of internal friction of soil samples and pore water pressure distribution in mine slopes. Factor of safety has been calculated by numerical modeling software OASYS using different slope angles. The outcome of study will be helpful in managing dump height.
\end{abstract}

\author{
Keywords \\ Angle of Internal Friction, Cohesion, Pore Water Pressure, Factor of Safety, Slope Stability
}

\section{Introduction}

Mining is the basic industry which helps in supply of metals, energy and minerals to other industries. Mother-nature has endowed India with good deposits of coal, bauxite, iron ore, limestone and other ores. Unfortunately India has one of the lowest per capita land availability and many deposits are under the forest cover. [1] To sustain high GDP growth rate Indian mining industry has to increase its contribution from present level of 2.6 percent to more than five percent in coming years. This calls for opening up of new mines, increasing output from existing mines and use of bigger size heavy earth moving machineries. Most of this increase is expected to come from opencast mines.

Opencast mines require large areas of land not only for production but also for stacking overburden rocks in the form of dumps. As land availability is low height of dumps is required to be increased. Steep slopes are favored because of economic reasons while low slopes are preferred due to stability issues. This calls for detail study of bearing capacities of land over which dumps are being formed along with factors which affects dump stability. [2]

\section{Basic Concept of Dump Slope Stability}

Stability of waste dumps depends upon slope angle and waste dump material properties like moisture content, permeability, grain size distribution, shear strength, cohesion and angle of internal friction. Other parameter which affects the stability of dumps is rainfall, mining method, blasting forces and seismic activity. The stability analysis includes determination of factor of safety for various slope angles considering above mentioned parameters.[3] Slope materials have tendency to slide due to shearing stresses created in the soil by gravitational and other forces like water flow, tectonic stresses, seismic activity, etc. [4] This tendency is resisted by the shear strength of slope materials which is expressed in the form of cohesion and angle of internal friction. Mohr Coulomb theory describes relationship of shear strength of the soil with cohesion, normal stresses and angle of internal friction as

$\mathrm{S}=\mathrm{c}+\sigma \tan \varphi$

The shearing stress along the failure surface is responsible for failure when it exceeds the shear strength of the soil

$\tau=\frac{S}{F O S}$

So, factor of safety can be referred as resistance force divided by driving force.[6] If the safety factor is greater than 1 then the slope is assumed to be stable. However, for long term stability a value of 1.5 is considered in open cast mine.

\section{Experimentation}

Total of 4 samples have been taken out from different locations from a coal mine dump near Nagpur. Standard proctor tests were conducted to determine maximum dry density and optimum moisture content. Direct shear test was conducted to determine cohesion and angle of internal friction. The results are tabulated below. The tests were conducted as per IS codes : 2720 part VII and part 13 methods of testing of soil. These parameters were used for calculating factor of safety and consequently the slope stability using OASYS 9.1 slope software by varying slope 
angle and pore water pressure values. Study has been further extended to consider pore water pressure in soil dump material accounting rainfall effect. [5]

\begin{tabular}{|l|c|l|l|l|l|l|}
\hline Sr. & Description & \multicolumn{2}{|c|}{ Standard Proctor Test } & \multicolumn{2}{c|}{ Direct shear Test } \\
\cline { 3 - 7 } No. & $\begin{array}{c}\text { Bulk } \\
\text { Density } \\
\mathbf{k N} / \mathbf{m}^{3}\end{array}$ & $\begin{array}{c}\text { Dry } \\
\text { Density } \\
\mathbf{k N / \mathbf { m } ^ { 3 }}\end{array}$ & $\begin{array}{c}\text { Optimum } \\
\text { Moisture } \\
\text { Content \% }\end{array}$ & $\begin{array}{c}\text { Cohesion } \\
\mathbf{k N} / \mathbf{m}^{\mathbf{2}}\end{array}$ & $\begin{array}{c}\text { Angle of } \\
\text { Shearing } \\
\text { Resistance } \\
\mathbf{( d e g})\end{array}$ \\
\hline 1 & $\begin{array}{c}\text { Fine grain sandstone grains 223m } \\
\text { RL-254 }\end{array}$ & 18.76 & 15.70 & 19.50 & 48 & 7.5 \\
\hline 2 & Sandstone 32m RL- 251 & 19.07 & 16.50 & 15.60 & 20 & 17.5 \\
\hline 3 & Sandstone 43m & 19.19 & 16.80 & 14.20 & 17 & 22.5 \\
\hline 4 & $\begin{array}{c}\text { soil with silt and loose grains of } \\
\text { sandstone 0 m RL- 283 }\end{array}$ & 18.96 & 15.80 & 20.00 & 55 & 4 \\
\hline
\end{tabular}

Table 1: Results of Soil Samples

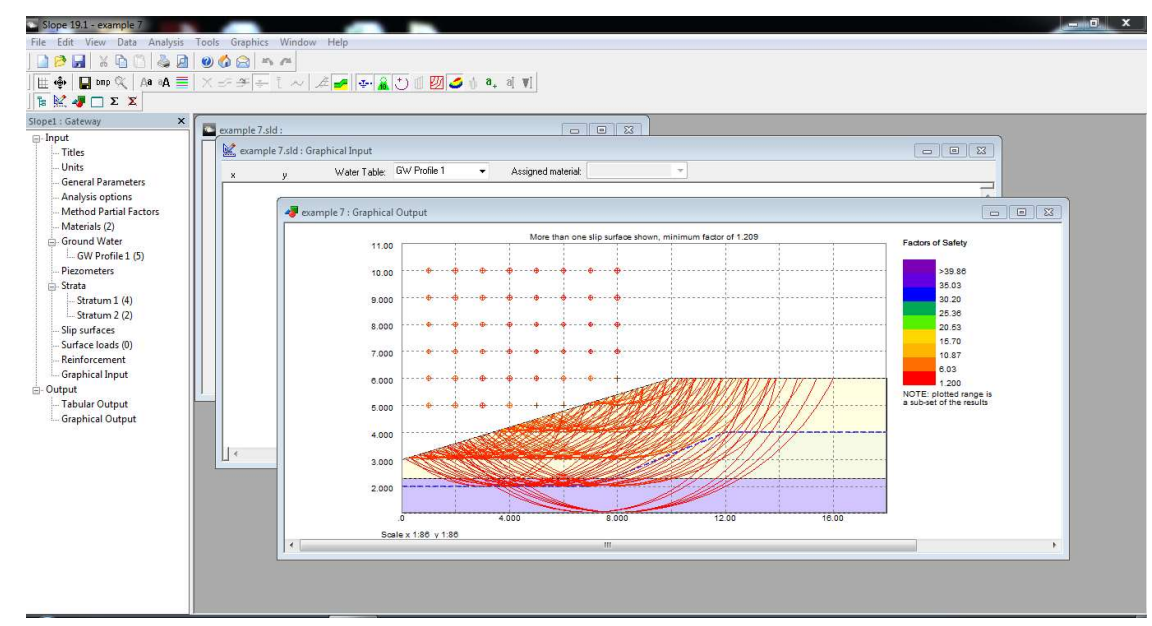

Fig 1: Defining Model in OASYS 9.1 SLOPE Software

\begin{tabular}{|c|c|c|c|c|c|}
\hline $\begin{array}{l}\text { Sr. } \\
\text { No. }\end{array}$ & Description & Cohesion & $\Phi(\operatorname{deg})$ & $\begin{array}{l}\text { Slope } \\
\text { Angle }\end{array}$ & FOS \\
\hline \multirow[t]{4}{*}{1} & \multirow[t]{4}{*}{ Fine grain sandstone grains $223 \mathrm{~m}$ RL-254 } & \multirow[t]{4}{*}{48} & \multirow[t]{4}{*}{7.5} & 18 & 4.62 \\
\hline & & & & 20 & 4.4 \\
\hline & & & & 22 & 4.26 \\
\hline & & & & 24 & 3.80 \\
\hline \multirow[t]{4}{*}{2} & \multirow[t]{4}{*}{ Sandstone $32 \mathrm{~m}$ RL- 251} & \multirow[t]{4}{*}{20} & \multirow[t]{4}{*}{17.5} & 18 & 2.63 \\
\hline & & & & 20 & 2.58 \\
\hline & & & & 22 & 2.43 \\
\hline & & & & 24 & 2.10 \\
\hline \multirow[t]{4}{*}{3} & \multirow[t]{4}{*}{ Sandstone $43 \mathrm{~m}$} & \multirow[t]{4}{*}{17} & \multirow[t]{4}{*}{22.5} & 18 & 1.45 \\
\hline & & & & 20 & 1.30 \\
\hline & & & & 22 & 1.20 \\
\hline & & & & 24 & 0.72 \\
\hline \multirow[t]{4}{*}{4} & \multirow{4}{*}{$\begin{array}{l}\text { soil with silt and loose grains of sandstone } 0 \\
\text { m RL- } 283\end{array}$} & \multirow[t]{4}{*}{55} & \multirow[t]{4}{*}{4} & 18 & 3.8 \\
\hline & & & & 20 & 3.72 \\
\hline & & & & 22 & 3.61 \\
\hline & & & & 24 & 3.20 \\
\hline
\end{tabular}

Table 2: Results Obtained from Varying Slope Angle 


\begin{tabular}{|c|c|c|c|c|c|}
\hline Sr. No & Description & Cohesion & $\Phi(\mathrm{deg})$ & Ru Value & FOS \\
\hline \multirow[t]{4}{*}{1} & \multirow{4}{*}{$\begin{array}{l}\text { Fine grain sandstone grains } 223 \mathrm{~m} \text { RL- } \\
\qquad 254\end{array}$} & \multirow[t]{4}{*}{48} & \multirow[t]{4}{*}{7.5} & 0.2 & 3.31 \\
\hline & & & & 0.4 & 3.22 \\
\hline & & & & 0.6 & 3.12 \\
\hline & & & & 0.8 & 3.02 \\
\hline \multirow[t]{4}{*}{2} & \multirow[t]{4}{*}{ Sandstone $32 \mathrm{~m}$ RL- 251} & \multirow[t]{4}{*}{20} & \multirow[t]{4}{*}{17.5} & 0.2 & 1.70 \\
\hline & & & & 0.4 & 1.57 \\
\hline & & & & 0.6 & 1.40 \\
\hline & & & & 0.8 & 1.24 \\
\hline \multirow[t]{4}{*}{3} & \multirow[t]{4}{*}{ Sandstone $43 \mathrm{~m}$} & \multirow[t]{4}{*}{2} & \multirow[t]{4}{*}{22.5} & 0.2 & 0.50 \\
\hline & & & & 0.4 & 0.39 \\
\hline & & & & 0.6 & 0.25 \\
\hline & & & & 0.8 & 0.10 \\
\hline \multirow[t]{4}{*}{4} & \multirow{4}{*}{$\begin{array}{l}\text { soil with silt and loose grains of } \\
\text { sandstone } 0 \mathrm{~m} \text { RL- } 283\end{array}$} & \multirow[t]{4}{*}{55} & \multirow[t]{4}{*}{4} & 0.2 & 3.55 \\
\hline & & & & 0.4 & 3.50 \\
\hline & & & & 0.6 & 3.44 \\
\hline & & & & 0.8 & 3.37 \\
\hline
\end{tabular}

Table 3: Results Obtained from Varying RU Value (Pore Pressure/Overburden Pressure)

\section{Results}

The cohesion values obtain above suggest that factor of safety improves with increase in the value of cohesion. As the samples were of very weak formation affect of angle of internal friction on factor of safety is not clearly evident.

\section{Conclusion}

The results of the experiments conducted were used to run various models using OASYS 9.1 slope software. It is noted that the FOS reduces with increase in dump slope angle. It is also evident that stability increases with increase in both cohesion \& angle of internal friction. It can be concluded that the factor of safety increases by updating the search radius \& angle of rotation in OASYS. Considering the effect of pore water pressure, the stability reduces with constant cohesion and angle of shearing resistance. Earth soil has maximum value of cohesion and found safer considering geometric parameters and pore pressure distribution. Dump height and other bench parameters have not been taken into consideration in this study.

\section{References}

1. Dump stability of chromite mines : A case study, Dr K Pathak etc, All India seminar, SSIOMCE - 15, organized by NIT, Rourkela, July 25 -26, 2015.

2. Effcet of gradation, gravel content and fragment size on the compaction and shear strength behavior of coal mine overdump material, P K Dewangan etc, All India seminar, SSIOMCE - 15, organized by NIT, Rourkela, July 25 -26, 2015.

3. Rock Dynamics- An over view, R K Goyal, seminar on geotechnical challenges in infrastructure projects, 25-26, April, 2013, New Delhi, organised by Central Board of Irrigation and Power.

4. Deformability and shear strength characteristics of granite rock mass, G V Raman, S Phatak, Hari Dev, seminar on geotechnical challenges in infrastructure projects, 25-26, April, 2013, New Delhi, organized by Central Board of Irrigation and Power

5. Application of OASYS slope program for mining engineering problems, A Vishal Kumar, Short term course on Instrumentation, 27-30 November, NIT, Rourkela.

6. www.ecoursesonline.iasri.res.in 